\title{
The Pastoral Role Of The Church In Building Spirituality Among Sex Workers And Transgenders In Medan
}

\author{
Natanael \\ \{nathan.24.ngt@gmail.com\} \\ Postgraduate Program, Pelita Kebenaran School of Theology
}

\begin{abstract}
The pastoral role of the church in in building spiritual the life of sex workers and transgenders is very important. Nowadays many churches are merely concerned with the interests of church members and lack concern for issues outside the church congregation. Meanwhile prostitute and a transvestite who is out there need assistance and spiritual guidance from a church. Many sex workers and transgenders do not know the direction and purpose of their lives so that they live far from God and become deeper into sin. Many people who avoid this group even see them as people who must be destroyed. Whereas know it is known every soul is precious in the eyes of God. If all thought of the matter the same way, these souls would perish. The church fails to fulfill the Great Commission of the Lord Jesus pertaining to the salvation of souls. The church in its responsibility to provide pastoral care must understand people comfortably become sex workers and transgenders. The church must be able to provide pastoral care for them so that they may have proper and holy lives before God. Churches should not be hostile to them but rather must be must embrace them. Pastoral formation for them must go through special approaches so that they would not feel left alone, that there are those who would minister to them. Such approaches can transform the paradigm of sex workers and transgenders, motivating them to repent and be born again as people of God.
\end{abstract}

Keyword : Building Spirituality, Sex workers, Transgenders

\section{Introduction}

Commercial sex workers (CSW) and transgenders (TGs) are not newly heard and foreign issues in the society. In fact they are despised by many people and are considered trash and even more cruelly, they may be regarded as animals. According to Nur Syam, the profession of a prostitute is very risky as they utilize their bodies as a commodity or instrument for economic gain. Even though they know that the action is self-destructive and causes great problems for their personal lives and also for their family. It is likewise with TGs who also sacrifice their bodies, i.e., vital parts. Of course, particularly the topic of TGs is treated taboo to be discussed, but this problem is not a secret in society. Often the TGs may feel disadvantaged by their circumstances, however not being able to do change their situation. On the other hand people in general mostly know how to insult and despise this group of people when in contrast they must be embraced and guided in the right direction.

There are different perspectives concerning the many factors that may cause a person to become a prostitute or transvestite. Some of the factors are as follows. Economy and 
environmental factors. For the TGs the most influencing factor is the presence of physical disorder. Therefore, the church must be present in guiding them. If there is sex worker or transvestite coming to church and the congregation knows it, the church and the church workers should not stay away from them, many of them come to church and the congregation say, "what do they come to church for? They only come to pollute the church." These words actually made them think that their lives are rejected in society. From this the church should open their eyes, change their mindset that people who to come church must be accepted with open arms. Because they are also the property of God who is lost and the church is responsible for saving them

Pastoral Counseling is one of several forms of service that is in the Church. Through pastoral counseling the church can help congregations or people outside the church environment to maximize their lives and change their lives and build their spirituality individually or in groups to become closer to the creator, namely Lord Jesus. Thus pastoral counseling is the realization of theology that is done in real life. Pastoral Counseling ministry is a service that we must provide to CSW and transgeders. In real life there are many problems experienced by church congregations especially the problems that will be discussed, namely the problem of CSW and TGs. What are the actions and pastoral roles of the church in fostering the spirituality of CSWs and TGs? This study examines the importance of the pastoral role of the Church in fostering spirituality of CSWs and TGs in Medan City. The formulation of the questions is as follows:

1. What is the factor that causes a person to become a sex worker?

2. What factors turn someone into a transvestite?

3. What is the cycle of increasing CSW from 2016 to 2018 ?

4. What is the cycle of increasing TGs from 2016 to 2018 ?

5. What is the response of the Church regarding the existence of CSW and TGs?

6. What kind of pastoral counseling can be provided to CSW and transgender women?

This research was carried out in the Medan city area, especially the separate terrain areas where many CSWand transgender people settled in this area and also many churches in this area. This study aims to describe the profile of CSW and TGs in Medan in and church attitudes towards CSW and TGs and pastoral counseling on what the church will give them.

\section{Discussion}

Based on the interviews, the following are the factors that influence why they become CSW and TGs.

Table 1. Factors that influence a person to become a sex worker

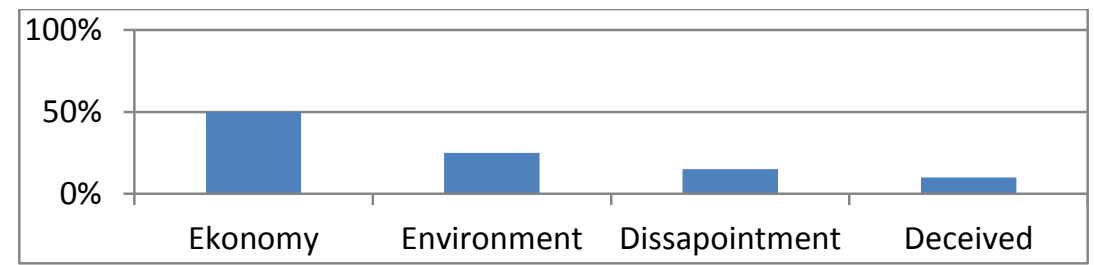

Information: 
- Data from the table shows the main factors why a person becomes a sex worker is economy. Because of the current high level of the economy, a person is forced to sell self to improve family's economy.

- Second is the environmental factor. So many young people are influenced by free social environment that they fall into it and have difficulty getting out of the influence of the environment.

- Third is the disappointment factor that is a factor because there is a deep hurt so that someone becomes a sex worker.

- Gratitude is a factor in Deception. Someone who lives in the countryside is invited to work in the city and when she arrives in the city she is sold by pimps.

Table 2. Factors that influence a person to become a transvestite

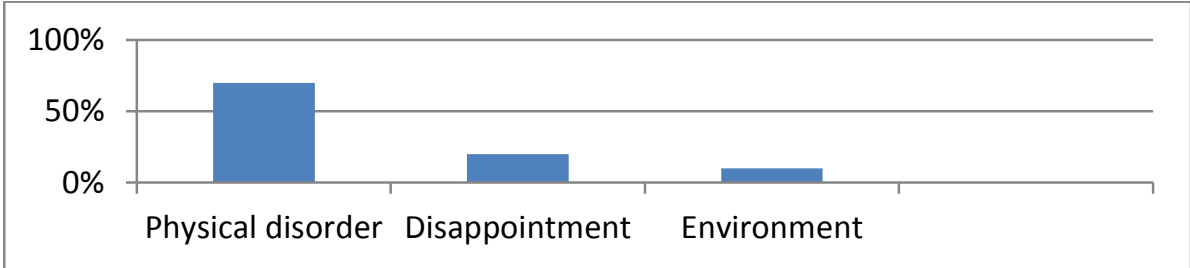

Information: disappointment

- Data from the table shows the main factors why a person becomes a transvestite is a psychical disorder factor, where from the table above shows $70 \%$ as the highest percentage.

- Second is the Factor of Disappointment. This is experienced by someone in the family, namely violence in the family.

- Third is an environmental factor where a man has more friends of TGs so that he is much affected and eventually becomes a transvestite.

Table 3. Number of sex workers, 2016-2019

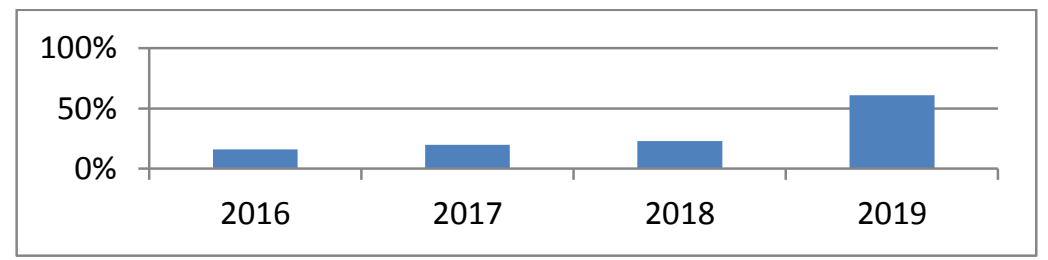

Information:

From the table above, it can be seen that the increase in CSW from 2016 to years, even in 2019 it continues to increase. This means that the CSW in Medan City increases every year, and even in 2019 the increase is very significant.

Table 4. Number of TGs, 2016-2019 


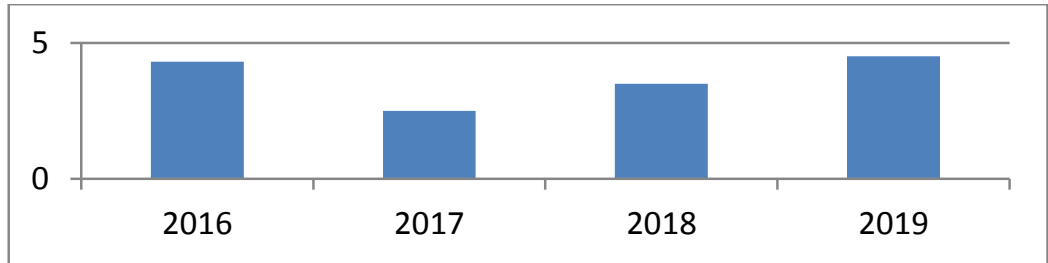

Information:

From the table above, it can be seen that the TGs from 2016 to 2017 has decreased but in 2018 and even up to 2019 it has increased due to the lack of public awareness to counter the increase of transgender women in the city of Medan.

Table 5. GBI Gatot Subroto members' response towards sex workers and TGs

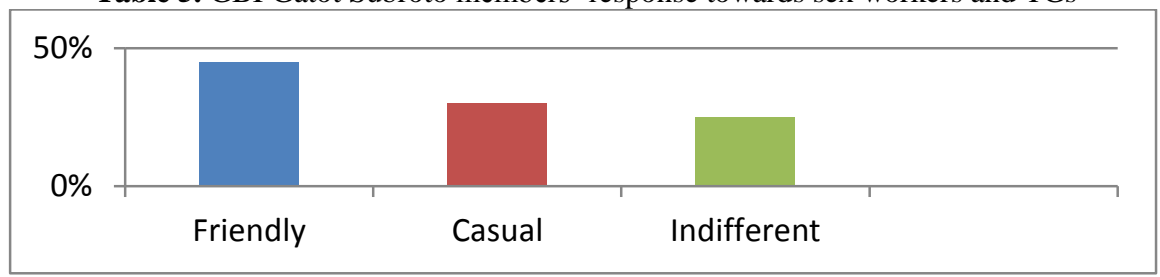

Information:

- Data from the table shows GBI Gatot Subroto's response to friendly CSW and transgender people, which is about $45 \%$ why because according to them if we are not friendly to them, how can they be embraced and be fostered in their spirituality.

- There were also responses from some ordinary congregations because there are many neighborhoods around the church where CSW \& TGs wander around.

- The last response was indifferent, there were also congregations who ignored the CSW and TGs who came to church because they thought why we should take care of them while their own life was not right in God's eyes. Some people interviewed in the church revealed this.

Based on all the above discussion, there is a very necessary church pastoral role for CSW and TGs because they also want to live better, but it is difficult for them to find it. In this situation, the church must be careful in responding to it. Some of the approaches that can be taken to foster Spirituality of CSW and TGs are as follows.

1. Personal Counseling

Personal counseling is very necessary to find out the root of the problem. A counselor in the church pastoral division must know what causes a person to become CSW and TGs.

2. Pray and confess mistakes

After a prostitute and transvestite had told him what he was complaining about, a pastoral counselor can invite them to pray and confess all his mistakes.

3. Fellowship

After someone has acknowledged his mistake and is willing to repent, invite him to get closer to God, namely by following the fellowship in the Church. The fellowship that they follow will bring them spirituality deeper with God, becoming not of he past and focus on improving spirituality with God.

\section{Reference}


[1] Bdk. Nur Syam, Agama Pelacur-DramaturgiTransmental, (Yogyakarta:LKIS, 2010) hal.5

[2] Cecille hoigard\&liv Findstand,Tubuhku bukan milikmu-prostitusicinta,uang(Yogyakarta:Pustaka Pelajar,2008) hal14.

[3] https://www.caraebit.com/2016/05/faktor-penyebab-menjadi-psk.html.

[4] http://brainly.co.id/tugas/9082992.

[5] Lihat Emanuel Gerrit Singh, Bergereja, Berteologi dan Bermasyarakat.(Yogyakarta: Taman Pustaka Kristen,2007)hal 60.

[6] https://www.e-jurnal.com.2013/09/faktor penyebab pelacuran.html.

[7] https://palembang.tribunnews.com/amp/2018/03/31/bukan-masalah-ekonomi.html [8]https//: medan.tribunnews.com/2016/12/02/agus -suryadi-mayoritas-pskpendatang.

[9]Berdasarkan penelitian Lapangan awal bulan februari 2019.

[10] https://docplayer.info/31672030-bab II-konseling-pastoral-gereja.html. 